\title{
THE STRATEGY FOR THE DEVELOPMENT OF KAMPUNG LABU MADU AGRO- TOURISM IN BESUK HAMLET, TOYORESMI VILLAGE, NGASEM DISTRICT, KEDIRI REGENCY, EAST JAVA PROVINCE, INDONESIA
}

\author{
Hamyana, Khanifatul Hidayawati, and Budianto \\ Politeknik Pembangunan Pertanian Malang, Indonesia \\ Correspondence Email: hams.lodaya@gmail.com
}

Submitted 18 July 2019; Accepted 10 May 2020

\begin{abstract}
ABSTRAK
Penelitian ini bertujuan untuk menemukan strategi pengembangan agrowisata di Kampung Labu Madu. Lokasi penelitian di Dusun Besuk, Desa Toyoresmi, Kecamatan Ngasem, Kabupaten Kediri. Pendekatan yang digunakan adalah pendekatan kuantitatif. Penelitian dilakukan selama 3 (tiga) bulan yakni bulan Maret - Mei 2019. Metode pengambilan data primer dilakukan dengan cara menyebarkan angket kepada responden yang terdiri dari dari kepala desa, kepala dusun, penyuluh pertanian dan anggota kelompok tani labu madu. Data yang terkumpul dianalisis menggunakan nalisis SWOT (Strenght, Weakness, Opportunity, Threat). Hasil penelitian menunjukkan strategi berada pada posisi Weakness - Opportunity (W-O) sehingga menghasilkan strategi Turn - Around yang berarti meminimalkan kelemahan dengan memanfaatkan peluang yang ada. Adapun strategi W-O yaitu: mensosialisasikan penerapan sapta pesona wisata sebagai pondasi agrowisata, meningkatkan kinerja kelompok labu madu dengan pembagian program kerja, diperlukan dukungan pemerintah dalam penyediaan fasilitas agrowisata sesuai Standart Operasional Prosedur (SOP) dan kebijakan pemerintah dalam menjamin kepastian legalitas agrowisata.
\end{abstract}

Kata kunci: agrowisata, labu madu, strategi

\begin{abstract}
The purpose of this research is to find the strategy in development "Kampung Labu Madu" Agrotourism. The research location was conducted in Besuk, Toyoresmi village, Ngasem District. Kediri Regency. The approach used is a quantitative approach. The study was conducted for 3 (three) months form March - May 2019. The primary data collection method was carried out by distributing questionnaires to respondents consisting of village heads, hamlet heads, agricultural extension workers and members of the "Labu Madu" farmer group. The collected data were analyzed using SWOT (Strength, Weakness, Opportunity, Threat) analysis. The results of the study show that the strategy is in the Weakness - Opportunity (W-O) position so as to produce a Turn - Around strategy which means minimizing weaknesses by exploiting existing opportunities. The W-O Strategy is : socializing the implimentation "Sapta Pesona Wisata" as an agrotourism foundation, improve the performance of "Labu Madu" farmer group in distributing work programs, needing goverment support in provision of agri tourism facilities to standart operacional procedure and policies in ensuring certanty of agritourism.
\end{abstract}

Keyword: agrotourism, labu madu, strategy

\section{INTRODUCTION}

The current development of the agricultural sector does not only require an increase in production, but aesthetics, education, and health have also become increasingly important to obtain the attention of the consumer community. Observing this 
condition, the concept of agro-tourism has become a major issue that has filled the space for discussion and research in recent years. The idea of presenting a more elegant, educative, dignified, modern agricultural image, and particularly by prioritizing local wisdom of local agricultural culture is the epicenter for future agricultural development.

According to the Tourism Law of 2009 , tourism is a travel activity carried out by a person or group of people by visiting certain places for the purpose of recreation, personal development, or learning the uniqueness of the tourist attraction visited for a temporary period. The current transformation of tourism not only explores natural beauty, but more than that, the process of natural resource management (such as agriculture, fisheries, animal husbandry, plantations, etc.) is starting to be seen as a promising new tourist attraction. The concept of agro-tourism as a manifestation of the unification of agricultural and tourism concepts brings innovation as a solution to improving the economy and welfare of rural farming communities. The development of agro-tourism is an effort to utilize the potential of agricultural tourism attractions (Tirtawinata and Fachruddin, 1996). Through the development of agro-tourism, it can be an opportunity to develop various agricultural commodities and highlight local wisdom in utilizing land and can create jobs.

In East Java, many regions have started to develop agro-tourism, including Kediri, Malang, Blitar, Trenggalek, Magetan, Banyuwangi, and many more. An agrotourism that is currently being the center of attention and the concentration of both the district government and private media is agrotourism in Kampung Labu Madu in Toyoresmi Village, Ngasem District, Kediri Regency.

Agro-tourism in Kampung Labu Madu has the potential for educational tourism which presents a whole series of direct activities from honey pumpkin cultivation techniques to the processing technology of honey pumpkin into healthy and nutritious food products. This management of educational tourism can provide feedback for farmers in terms of management of the Kampung Labu Madu to continue to make improvements in all aspects. Besides, the unique layout also makes it a special attraction for tourists because it can also be used as an interesting photo spot. In the process of running and developing agrotourism, there are certainly a number of communities that have important roles and contributions that are formed in one forum such as a group or organization.

Kampung Labu Madu was established because of the motivation that was built up from Sempu Village, which had already developed honey pumpkins and had a positive impact on the groups involved. Seeing this phenomenon, business players have initiated honey pumpkin in Toyoresmi Village to be developed so that it can have a positive impact on the main players involved. However, in reality, the development of the Kampung Labu Madu Agro-tourism has experienced several constraints, one of which is the innovation and application of the concept of tourism charm that has not been optimally implemented. Therefore, a strategy is required in analyzing the potential constraints and support for agro-tourism development using SWOT (Strengths, Weaknesses, Opportunities, Threats) analysis.

Based on the background, the problem is how to identify strategies that can be used in developing the agro-tourism area of Labu Madu Village. The purpose of this study was to identify the proper strategy in the development of the agro-tourism area of Kampung Labu Madu. This study is expected to be useful for development in the agrotourism area of Kampung Labu Madu.

\section{RESEARCH METHODS}

The research method used descriptive quantitative which was used to analyze the data by describing or illustrating the data that had been collected. The location of this study was Besuk Hamlet, Toyoresmi Village, 
Ngasem District, Kediri Regency. This study was conducted for 3 (three) months from March to May 2019. The location of the study was determined with the consideration that the Kampung Labu Madu Agro-tourism is one of the new agro-tourism in Kediri Regency which requires assistance and direction in developing tourism potential.

The determination of respondents who participated in the study used the Purposive Sampling technique, so that it obtained 6 (six) people consisting of the Head of Toyoresmi Village, the Head of Besuk Hamlet, an Agricultural Instructor, 2 managers of the tourist attraction, and the head of the honey pumpkin group farmer.

The data used in this study were primary data and secondary data. The primary data were data taken directly from the research location of the Kampung Labu Madu Agro-tourism area through direct observation at the site, interviews with government officials and community leaders, and filling out questionnaires. The secondary data were data obtained through related agencies in this study. These data included: the potential of the Toyoresmi Village area, the population, and the tourist attraction.

The analytical method used in identifying the strategy for developing the Kampung Labu Madu Agro-tourism area used SWOT analysis. The variables of this study included indicators of strengths, weaknesses, opportunities, and threats in the Kampung Labu Madu Agro-tourism area. According to Rangkuti (2015), the strategic planning process for SWOT analysis goes through 3 (three) stages, including:

1. Data collection stage

a. At this stage, to obtain the external data and internal data, an analysis of internal and external factors was carried out in the Kampung Labu Madu Agro-tourism area. This process generated data on aspects of strengths, weaknesses, opportunities, and threats (SWOT).

b. The questionnaire was compiled based on data on the strengths, weaknesses, opportunities, and threats of the
Kampung Labu Madu Agro-tourism. The questionnaire was spread to obtain a rating and weight for the SWOT aspects. The questionnaire used a measurement of the rating scale.

c. The distribution of questionnaires was carried out to 6 (six) key informants, including the parties who concern with and understand the conditions of the Kampung Labu Madu Agro-tourism including the instructors, the hamlet head, the village head, the agro-tourism owners, the operational managers, and the head of the honey pumpkin group farmer. Then, the rating and weighting of the questionnaire were conducted.

d. The results of filling out the questionnaire were then calculated, in which the weight value was obtained from the total score of each indicator divided by the number of respondents. The item weight value was obtained by dividing the weight by the total weight of each aspect (strengths, weaknesses, opportunities, and threats).

2. Making a SWOT position mapping

The SWOT position mapping making used a SWOT diagram, then the position of the coordinate points obtained was observed. The position diagram of the agro-tourism development provided an overview of the state of agro-tourism development based on the quadrants generated by the SW Vector line and the OT Vector line, in which each quadrant had its main strategy formula. The formulation of each quadrant is as follows:

a. Quadrant I: Aggressive strategy is a favorable situation. The agro-tourism has opportunities and strengths so that it can take advantage of existing opportunities. The strategy that must be applied in this condition is to support a growth-oriented strategy.

b. Quadrant II: Diversification strategy. In this position, even though it faces various threats, this agro-tourism still has strength from an internal perspective. The strategy that must be 
applied is to use the strength to take advantage of long-term opportunities by means of a diversification strategy (product/market).

c. Quadrant III: Turn-around strategy. In this position, agro-tourism faces enormous market opportunities, but on the other hand, it faces several internal constraints/weaknesses. The focus of this agro-tourism strategy is to minimize the internal agro-tourism problems so that it can seize better market opportunities.

d. Quadrant IV: Defensive strategy is a very unfavorable situation, in which the agro-tourism faces various threats and internal weaknesses.

3. The formulation stage of compiling strategic factors through the SWOT matrix This matrix can clearly describe how the external opportunities and threats faced by Kampung Labu Madu Agro-tourism can be adjusted according to its strengths and weaknesses. The SWOT matrix can be seen in Table 1.

Based on the results of the rating and weighting values which are then multiplied, a combination of the following situations will be obtained (Rangkuti, 2015):

\section{SO Strategy}

This strategy is made by utilizing all strengths to seize and take advantage of opportunities as much as possible.

2. ST Strategy

This strategy is a strategy in using the strengths of agro-tourism to overcome threats.

3. WO Strategy

This strategy is implemented based on the use of existing opportunities by minimizing existing weaknesses.

\section{WT Strategy}

This strategy is based on defensive activities and it seeks to minimize existing weaknesses and avoids threats.

\section{RESULT AND DISCUSSION}

\section{Overview of Kampung Labu Madu Agro- tourism}

The establishment of Kampung Labu Madu was motivated by the aspirations of one of the residents of Toyoresmi Village who also served as the chairman of the Micro, Small, and Medium Enterprises of Kediri. He thought that the people in Toyoresmi Village have the potential for creativity that can be developed. To foster community interest, he took the initiative to provide a stimulus through a comparative study in villages that had developed honey pumpkin first, involving 11 people from farmer groups in the subsector. The results of the comparative study indicated that there was interest from farmers in cultivating honey pumpkins. As initial capital, he gave farmers a loan of IDR $7,000,000$. The loan was managed by the farmers to cultivate honey pumpkins by utilizing the drainage fringe of the village road. From the initial capital of IDR $7,000,000$, in one harvest, it can generate a profit of IDR 13,500,000.

Seeing this potential, the community followed up by planning the development of an agro-tourism based on the honey pumpkin commodity. To build the image of the Kampung Labu Madu as an agro-tourism area, it requires the role of the media with the moments of commemorating the Pancasila Sanctity Day and the Indonesian National Armed Forces Day. Through these moments, the community held an event of a honey pumpkin harvest and a green walk.

Table 1. SWOT Matrix

\begin{tabular}{ccc}
\hline & IFAS & Threats $(\mathrm{T})$ \\
\hline EFAS & Strengths $(\mathrm{S})$ & \\
\hline Opportunities $(\mathrm{O})$ & Strategy for SO & Strategy for WO \\
Weaknesses $(\mathrm{W})$ & Strategy for ST & Strategy for WT \\
\hline
\end{tabular}

Source: Researcher, 2019 
From this event, it is expected that Kampung Labu Madu can be recognized by a wide public without having to spend a large amount of promotional capital. That moment had a wide impact on Kampung Labu Madu, so that the community agreed that October 1 , 2016, was claimed to be the day of the establishment of Kampung Labu Madu Agrotourism. The major impact perceived by farmers was a warm welcome from the government with the awarding of the village gift as a creative village in exchange for giving IDR $100,000,000$ to develop the agrotourism in a commercial direction.

Analysis of the Strategy for the Development of Kampung Labu Madu Agro-tourism Area

The results of identification of the Internal Environment and External Environment can be seen in Table 2.

\section{Internal Factor Analysis (IFAS)}

The internal environmental analysis was carried out on the internal strategic factors consisting of strengths and weaknesses in the development of the
Kampung Labu Madu Agro-tourism area. The results of the analysis can be seen in Table 3.

Table 3 shows that the total score of the results of the internal analysis is 48, which indicates that the position of Kampung Labu Madu Agro-tourism area is in a "good" position in utilizing the strength to deal with the problems faced in the development of the agro-tourism area. The existing main strength of the Kampung Labu Madu Agro-tourism area is that it has good agro-tourism administration and management with a score of 8.8, supported by an extensive marketing partnership network in the Kampung Labu Madu Agro-tourism area with a score of 7.6. However, the main weakness in the Kampung Labu Madu Agro-tourism area is in the low group managerial implementation with a score of 13 and the application of tourism charm principles that have not been maximized and low suitability of facilities with the SOP with the same scores of 12 .

The management that is carried out in the Kampung Labu Madu Agro-tourism area can be seen from the implementation of the tourism charm principles which is quite good, even though they have not been fully implemented.

Table 2. Identification of Internal Environment and External Environment

\begin{tabular}{ll}
\hline \multicolumn{1}{c}{ INTERNAL } \\
\hline \multicolumn{1}{c}{ Strengths: } \\
1. A strategic tourist attraction \\
2. Administration and management of agro- \\
tourism \\
3. Potential Human Resources (HR) \\
4. Marketing partnership network \\
5. Information and communication systems
\end{tabular}

\section{EXTERNAL}

Opportunities:

1. Development of tourism investment forms

2. Market trends are in accordance with fresh and processed honey pumpkin products

3. The role of government and society

4. Funding partnership network

1. Application of the tourism charm 1. Pest control principles

2. Season change

2. The legality and legal protection of agrotourism

3. The interests of external parties in agrotourism

3. Suitability of facilities with Standard 4. Competition between tourism attractions Operating Procedure (SOP)

5. Market trend stability conditions

4. Group managerial implementation

6. Land conversion and land degradation 
Table 3. IFAS Matrix

\begin{tabular}{|c|c|c|c|c|c|}
\hline No & Strengths & Weight & Rating & Score & Priority \\
\hline 1. & Strategic tourist attraction & 4,2 & 1,2 & 5 & 5 \\
\hline 2. & $\begin{array}{l}\text { Administration and management of } \\
\text { agro-tourism }\end{array}$ & 4 & 2,2 & 8,8 & 2 \\
\hline 3. & Potential Human Resources (HR) & 4 & 4,2 & 17 & 1 \\
\hline 4. & Marketing partnership network & 5,4 & 1,4 & 7,6 & 3 \\
\hline 5. & Information and communication systems & 5,2 & 1,2 & 6,2 & 4 \\
\hline & Total Score & 23 & 10 & 44 & \\
\hline No & Weaknesses & Weight & Rating & Score & Priority \\
\hline 1. & $\begin{array}{l}\text { Application of the tourism charm } \\
\text { principles }\end{array}$ & 2,6 & 4,8 & 12 & 2 \\
\hline 2. & $\begin{array}{l}\text { The legality and legal protection of agro- } \\
\text { tourism } \\
\text { Suitability of facilities with Standard }\end{array}$ & 3,2 & 3,4 & 11 & 4 \\
\hline & Operating Procedure (SOP) & 2,4 & 4,8 & 12 & 3 \\
\hline 4. & Group managerial implementation & 3,2 & 4 & 13 & 1 \\
\hline & Total Score & 11 & 17 & 48 & \\
\hline & Difference & & & -3 & \\
\hline
\end{tabular}

Source: Primary Data, 2019

However, this is a good asset in improving the agro-tourism management carried out in the Kampung Labu Madu Agrotourism area. Referring to the results of a study by Mulyono and Mubarok (2019), it is stated that agro-tourism management is a very important key in constructing good and competitive agro-tourism. Meanwhile, the results of a study by Suryawan, Windia, and Sarjana (2018) stated that the participation of group members is a significant factor in developing agro-tourism.

\section{External Factor Analysis (EFAS)}

The external condition analysis was carried out on the strategic factors consisting of opportunities and threats in the development of the Kampung Labu Madu Agro-tourism area. These external strategic factors can be seen in Table 4.

The results of the analysis of external strategic factors through opportunities and threats obtained a total score of the external analysis of 43 which indicates that the development of Kampung Labu Madu Agrotourism area is in an external position of

"good" in taking advantage of opportunities to overcome the threats encountered. The biggest opportunity in the development of the Kampung Labu Madu Agro-tourism area is the development of various forms of agrotourism investment with a score of 21 and high government and community support with a score of 17 . Besides, the main threat is land conversion and land degradation in the Kampung Labu Madu Agro-tourism area due to tourism development with a score of 12 and unpredictable market trend stability conditions with a score of 10 .

\section{Mapping the Position of Kampung Labu Madu Agro-tourism Area}

The position of the agro-tourism was determined by combining the strengths, weaknesses, opportunities, and threats so that the coordinate points can be determined and mapped on a position matrix. The position of the coordinate points can be seen in the Cartesian coordinates below. 
Table 4. EFAS Matrix

\begin{tabular}{|c|c|c|c|c|c|}
\hline No & Opportunities & Weight & Rating & Score & Priority \\
\hline \multirow{2}{*}{$\begin{array}{l}1 . \\
2 .\end{array}$} & Development of tourism investment forms & 4,4 & 4,8 & 21 & 1 \\
\hline & $\begin{array}{l}\text { Market trends are in accordance with } \\
\text { fresh and processed honey pumpkin } \\
\text { products }\end{array}$ & 6 & 2 & 12 & 3 \\
\hline 3. & The role of government and community & 3,8 & 4,6 & 17 & 2 \\
\hline & Funding partnership network & 3,8 & 2,8 & 11 & 4 \\
\hline & Total Score & 18 & 14 & 61 & \\
\hline No & Threats & Weight & Rating & Score & Priority \\
\hline 1. & Pest control & 4,6 & 1,6 & 7,4 & 4 \\
\hline 2. & Season change & 1,2 & 1,2 & 1,4 & 6 \\
\hline \multicolumn{2}{|r|}{$\begin{array}{l}\text { 3. The interests of external parties in agro- } \\
\text { tourism }\end{array}$} & 3,6 & 1,2 & 4,3 & 5 \\
\hline & Competition between tourism attractions & 3,6 & 2,2 & 7,9 & 3 \\
\hline 5. & Market trend stability conditions & 3,6 & 2,8 & 10 & 2 \\
\hline & Land conversion and land degradation & 2,8 & 4,2 & 12 & 1 \\
\hline & Total Score & 19 & 13 & 43 & \\
\hline & Difference & & & 18 & \\
\hline
\end{tabular}

Source: Primary Data, 2019

Based on the results, Figure 1 shows opportunities and strengths so that they can that the relative position of the Kampung Labu Madu Agro-tourism area is at the take advantage of existing opportunities. The strategy that must be applied in this condition coordinate point of $(-3,18)$ in quadrant II. The strategy in this position is a very favorable situation where in the development is to minimize internal problems in agrotourism so that it can seize better opportunities.

of organic farming areas, young farmers have

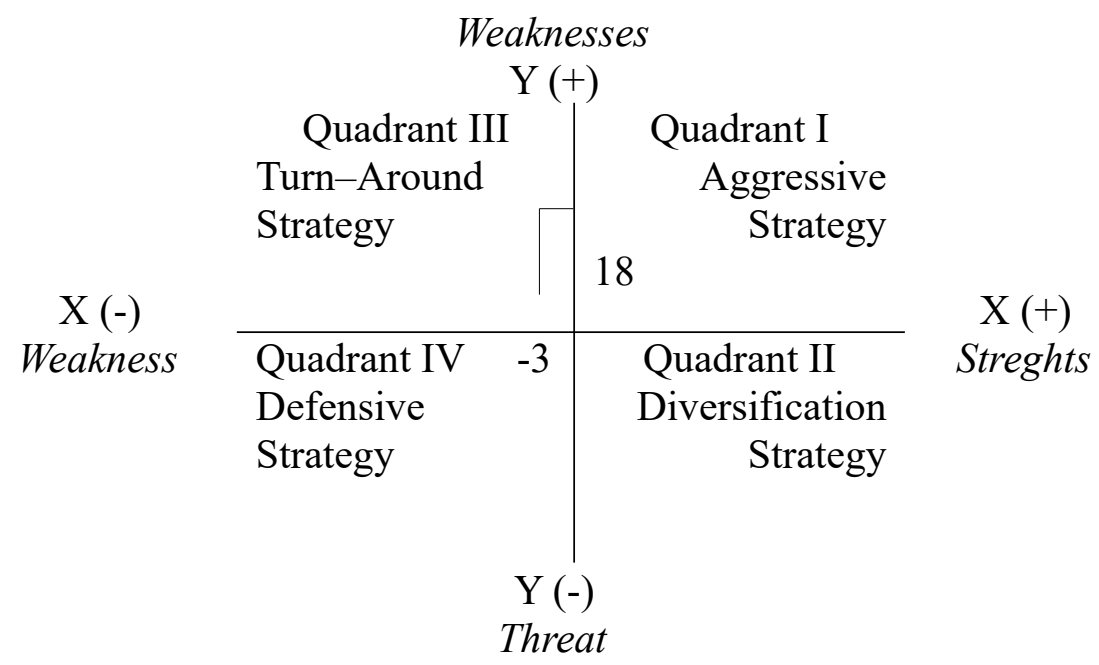

Figure 1. Matrikx of Agrotourism Development

Source: Primary Data, 2019 
The Strategy for the Development of Kampung Labu Madu Agro-tourism Area

Based on the results of the mapping of the position of Kampung Labu Madu Agrotourism area development, the strategic factors were then arranged in the form of a SWOT matrix which resulted in several strategic alternatives, including the following:

1. SO Strategy

a. Improving the skills of Human Resources (HR) to develop various forms of tourism investment and agrotourism products.

b. Optimizing information and communication systems that are good enough to establish partnerships with external parties.

c. A mentoring role is required by the government in managing the administration and management of the agro-tourism.

2. ST Strategy

a. Carrying out an outreach regarding the negative impact of the construction of permanent facilities at the agro-tourism site on land conversion and land degradation.

b. Making a cooperation agreement with the marketing sector to obtain market stability.

c. Improving the administration and management system of the agro-tourism to suppress competition between tourism attractions and preventing any external party interests that are detrimental to the agro-tourism.

d. Increasing the application of the latest technology in the prevention and handling of Plant Pest Organisms (OPT) and unexpected season changes.

3. WO Strategy

a. Carrying out an outreach regarding the application of tourism charm principles as the foundation of agro-tourism by involving the government and the community which will make it easier to develop various forms of tourism investment. b. Improving the performance of the honey pumpkin group by dividing work programs according to divisions to help meet market demand.

c. Kampung Labu Madu Agro-tourism area will be assisted in the development process if the government provides support in the form of the availability of facilities according to the SOP.

d. Support in the form of government policies is required to guarantee independent legality and legal protection certainty that will make it easier to establish partnerships with external parties.

4. WT Strategy

a. Implementing tourism charm principles in the construction of facilities according to the SOP by paying attention to environmental aspects.

b. Using legality and legal protection to prevent the involvement of external parties that can harm the agro-tourism.

c. Conducting training to develop agrotourism products in following market trends.

d. Training members to be responsive in the prevention and handling of Plant Pest Organisms (OPT).

e. Improving the performance of members to keep up with competition from other tourism attractions.

Based on the explanation above, it shows that the Kampung Labu Madu Agrotourism area is in a position of great opportunity. The strategy recommendation given is to turn-around, meaning that the Kampung Labu Madu Agro-tourism area is in a condition that has a very high market opportunity but it still has to pay attention to internal weaknesses/constraints. Therefore, the strategy that must be carried out is to minimize internal problems to seize better market opportunities. Thus, the strategy recommendation provided is the WO strategy.

This is different from the results of a study conducted by Palit, et al. (2017) which generated several agro-tourism development strategies on the SO strategy, which is by 
utilizing several existing tourist attractions to attract investors, utilizing agro-tourism using its characteristics, and utilizing good soil fertility levels in the agro-tourism area. A study by Widitomo and Santoso (2015) also showed different results with this study where the results of the development strategy design using SWOT generated four competitive strategies, including market penetration, product development, forward integration, and concentric diversification. Based on the QSPM analysis, a suitable and effective development strategy applied to the Kampoeng Kopi Banaran Agro-tourism is a product development strategy (score 5.829). In addition, the second priority is a market penetration strategy (score of 5,751) and a forward integration strategy (score of 4,686).

However, the results of this study are in line with Rhamwati, et al. (2017) who stated that the application of the concept of tourism awareness is important in the basis of agro-tourism development because it can encourage the public awareness and can attract tourists to visit an area. A similar argument was also expressed in the results of a study by Suryawan, Windia, and Sarjana (2018) which stated that the participation of group members is a significant factor in developing agro-tourism.

\section{CONCLUSIONS}

Several strategies for the development of the agro-tourism that can be implemented included: 1) carrying out an outreach regarding the application of tourism charm principles as the foundation of agro-tourism, 2) improving the performance of the honey pumpkin group, 3) government support in providing agro-tourism facilities in Kampung Labu Madu Agro-tourism, and 4) government policies on legality and legal protection to establish partnerships with external parties. Recommendations that can be suggested are an increase in community participation in the development of agro-tourism and for the government to further increase the intensity of counseling and assistance to honey pumpkin groups regarding agro-tourism management.

\section{REFERENCES}

Ardiansari, R., E. E. Nurlaelih, and K. P. Wicaksono. 2015. Pengembangan agrowisata di Desa Wisata Tulungrejo Kota Batu Jawa Timur. Jurnal Produksi Tanaman 3(5): 383-390.

Mulyono, J. and A. M. Mubarok 2019. Kontruksi agrowisata kelompok tani durian di Desa Kemuningsari Lor Kecamatan Panti Kabupaten Jember. Warta Pengabdian 13(3): 80-95.

Palit, I. G., Celcius, Talumingan, and G. A. J. Rumaagit. $2016 . \quad$ Strategi pengembangan Kawasan Agrowisata Rurukan. Jurnal Agri-SosioEkonomi 13(2): 21-34.

Pedoman Kelompok Sadar Wisata Direktorat Jenderal Pengembangan Destinasi Pariwisata Kementerian Pariwisata dan Ekonomi Kreatif. 2012. Jakarta. Persada.

Rahmawati, S. W., Sunarti, and L. Hakim. 2017. Penerapan sapta pesona pada desa wisata (analisis persepsi wisatawan atas layanan penyedia jasa di Kampung Wisata Kungkuk, Desa Punten, Kota Batu). Jurnal Administrasi Bisnis 50(2): 196-202.

Rangkuti, F. 2015. Analisis SWOT: Teknik Membedah Kasus Bisnis Cara Perhitungan Bobot, Rating, dan OCAI. Jakarta. PT. Gramedia Pustaka Utama.

Sugiyono. 2009. Metode Penelitian Kuantitatif Kualitatif dan R\&D. Bandung. Alfabeta.

Suryawan, I. W. D., I. W. Windia, and I. M. Sarjana. 2018. Model partisipasi petani dalam pengembangan agrowisata di Desa Kerta, Kecamatan Payangan, Kabupaten Gianyar. Jurnal Agribisnis dan Agrowisata 7(3): 415-423. 
Tirtawinata dan Fachrudin. 1996. Daya Tarik dan Pengelolaan Agrowisata. Jakarta. Swadaya.

Undang-Undang Republik Indonesia Nomor 10 Tahun 2009 Tentang Kepariwisataan. Jakarta. Bumi Aksara.

Widitomo, D. P. and H. Santoso. 2015. Penetapan strategi pengembangan wisata dengan menggunakan strategyformulation framework. Industrial Engineering Online Journal 4(1): 1-10. 